\title{
TRANSFORMASI PT ASKES (PERSERO) MENJADI BADAN PENYELENGGARA JAMINAN SOSIAL KESEHATAN
}

\author{
Veny Afrilia $^{1}$, Suwandi Sumartias ${ }^{2}$, dan Lukiati Komala Erdinaya ${ }^{3}$ \\ ${ }^{1}$ BPJS Kesehatan \\ ${ }^{2,3}$ Universitas Padjadjaran
}

\begin{abstract}
ABSTRAK
PT ASKES (PERSERO) diterpa berbagai persoalan dalam melayani urusan kesehatan. Tata kelola PT ASKES dinilai buruk dari layanan kesehatan masyarakat. Namun, setelah enam tahun berubah menjadi BPJS, dan terbitnya UU BPJS No 24 tahun 2011, masih ditemui berbagai hal menyimpang dari tujuan pembentukan UU tersebut. Selain diwarnai dengan ketidakjelasan mekanisme pelayanan dan pertanggungjawaban di tingkat dinas, juga lemahnya pengawasan serta buruknya sistem pelayanan di beberapa rumah sakit. Kini, pemegang kartu BPJS masih merasa "warga" kelas dua dalam memperolah layanan kesehatan. Penelitian ini bertujuan untuk menganalisis alasan yang melatarbelakangi transformasi PT Askes (Persero) menjadi BPJS Kesehatan. Metode yang digunakan dalam penelitian adalah metode kualitatif dengan pendekatan studi kasus. Teknik pengumpulan data dilakukan dengan wawancara, observasi, dan Studi Kepustakaan. Hasil penelitian menunjukkan bahwa alasan PT Askes (Persero) melakukan transformasi karena adanya keinginan dari pemerintah Indonesia untuk memenuhi kebutuhan masyarakat akan jaminan kesehatan yang terjangkau, dan memberikan manfaat serta tidak memberatkan masyarakat terutama dari segi finansial. Untuk pemahaman staf divisi pemasaran mengenai transformasi dari PT Askes (Persero) menjadi BPJS Kesehatan pada umumnya staf divisi pemasaran memahami transformasi sebagai upaya pemerintah dalam memajukan tingkat kesehatan dan taraf hidup masyarakat secara keseluruhan yang menjadi visi dan misi BPJS kesehatan. Sedangkan mengenai tanggapan peserta mengenai BPJS Kesehatan, peserta BPJS Kesehatan masih menganggap BPJS Kesehatan masih kalah bersaing atau kurang efektif jika dibandingkan dengan perusahaan-perusahaan asuransi swasta.
\end{abstract}

Kata-kata Kunci: Transformasi, transformasi organisasi, interaksionisme simbolik, PT Askes (persero), BPJS kesehatan

\section{PT ASKES PERSERO TRANSFORMATION INTO HEALTHCARE AND SOCIAL SECURITY AGENCY}

\begin{abstract}
PT ASKES (PERSERO) has been buffeted by various problems to serve health affairs. The governance of PT ASKES becomes a bad figure of public health service. And after six year turned into BPJS, the publication of BPJS Act No. 24 of 2011, still encountered various things deviate from the purpose of the establishment of the Act. In addition to being characterized by unclear service mechanisms and accountability at the official level, there is also poor supervision and poor service system in some hospitals. Now, the card holders of BPJS still feel second class "citizens" in obtaining health services. The purpose of this research was to analyze the reasons behind PT Askes Tranformation into BPJS Healthcare Security. The method that used in this research is qualitative method with case study approach. Research data collected by in-depth interviews, observation, and study of literature. The results showed that the reason why PT Askes transformation that is based on the desire of the Indonesian government to comply the needs of Indonesia people about affordable health guarantee, and provide more benefits and not to burden the people, especially in financial terms. For the marketing division staff understanding about PT Askes transformation into BPJS Healthcare Security, marketing division staff generally understand about this transformation as a form of Indonesian government's efforts in advance the level of Indonesian people health which is the vision and mission of BPJS Healthcare Security as well as the objectives of the organization. For the responses and perceptions of the participants about BPJS Healthcare Security, the participants of BPJS Healthcare Security still considers that BPJS Healthcare Security still unable to compete or less effective than private insurance companies.
\end{abstract}

Keywords: Transformation, organizational transformation, symbolic interactionism, PT Askes Persero, BPJS Healthcare Security

Korespondensi: Veny Aprilia, M.I.Kom. BPJS Kesehatan, Jl. Pelajar Pejuang 45, Turangga, Bandung, Kota Bandung, Jawa Barat. Email: veny.afrilia22@yahoo.com 


\section{PENDAHULUAN}

Dalam rangka pelaksanaan jaminan sosial bagi seluruh masyarakat Indonesia dalam bidang kesehatan, pada awal tahun 2014 pemerintah telah melakukan transformasi terhadap PT Askes (Persero) menjadi BPJS Kesehatan. Kehadiran UU No. 40 Tahun 2004 tentang Sistem Jaminan Sosial Nasional (SJSN) membuat pemerintah harus membentuk Badan Penyelenggara Jaminan Sosial (BPJS) dan hal tersebut diwujudkan melalui pengesahan UUNo. 24 Tahun 2011 Tentang Badan Penyelenggara Jaminan Sosial, dimana PT Askes (Persero) Persero resmi dibubarkan tanpa likuidasi dan menjadi BPJS Kesehatan Per 1 Januari 2014. BPJS Kesehatan ini kemudian menggantikan sejumlah lembaga jaminan sosial yang ada di Indonesia, seperti yang tercantum dalam UU No. 24 tahun 2011 yang menyebutkan bahwa Jaminan Sosial Nasional dikelola oleh BPJS, untuk Jaminan Kesehatan Nasional secara khusus diselenggarakan oleh BPJS Kesehatan (Humas BPJS, 2013).

Transformasi adalah perubahan rupa yang meliputi bentuk, sifat, dan fungsi. Transformasi mengubah secara cermat dan dramatis bentuk, penampilan dan karakter (KBBI, Edisi Ketiga, 2005: 1208 dan Oxford English Reference Dictionary, 2003: 1530). UU SJSN dan UU BPJS memberi arti kata 'transformasi' sebagai perubahan bentuk BUMN Persero yang menyelenggarakan program jaminan sosial, menjadi BPJS. Perubahan bentuk bermakna perubahan karakteristik badan penyelenggara jaminan sosial sebagai penyesuaian atas perubahan filosofi penyelenggaraan program jaminan sosial. Perubahan karakteristik berarti perubahan bentuk badan hukum yang mencakup pendirian, ruang lingkup kerja dan kewenangan badan yang selanjutnya diikuti dengan perubahan struktur organisasi, prosedur kerja dan budaya organisasi.

Transformasi PT Askes (Persero) menjadi BPJS Kesehatan dapat dikatakan merupakan sebuah hal baru bagi masyarakat Indonesia, yang paling mendasar adalah perubahan nama lembaga dari PT Askes (Persero) menjadi BPJS Kesehatan dan perubahan logo. Menurut Prayudi dan Juanita (dalam Pratama, 2015) Media Informasi Karyawan SCTV (2005), nama yang baik memiliki kriteria; (1) Nama terlihat khusus; (2) nama harus praktis; (3) Jelas secara grafis; (4) Sederhana dalam bentuk; (5) Satu pesan; (6) Sesuai dengan bisnis. Selain perubahan identitas organisasi, seperti nama, logo, struktur organisasi dan lain sebagainya, terdapat beberapa bagian yang baru di dalam PT Askes (Persero) yamg kini telah melakukan transformasi menjadi BPJS Kesehatan. Begitu pula dengan cakupan kepesertaan, sebelum menjadi BPJS Kesehatan, PT Askes (Persero) hanya melayani jaminan kesehatan untuk PNS, penerima pensiun, veteran dan perintis kemerdekaan beserta keluarganya. Saat ini, seluruh jaminan kesehatan masyarakat Indonesia ditangani oleh BPJS Kesehatan (M

Tujuan pembangunan kesehatan di Indonesia adalah tercapainya derajat kesehatan masyarakat yang setinggi-tingginya agar terwujud manusia Indonesia yang bermutu, sehat, dan produktif. Untuk mencapai tujuan pembangunan kesehatan tersebut harus dilaksanakan upaya kesehatan masyarakat dan upaya kesehatan perorangan. Kedua upaya tersebut adalah berupa pelayanan berkesinambungan atau continuum care. Upaya kesehatan masyarakat harus dilaksanakan pada sisi hulu untuk mempertahankan agar masyarakat tetap sehat dan tidak jatuh sakit, sedangkan upaya kesehatan perorangan dilaksanakan pada sisi hilir.

Sejak dulu asuransi kesehatan milik pemerintah atau yang biasanya dikelola oleh BUMN seringkali dirundung permasalahan yang berkepanjangan, misalnya sebagai contoh yaitu permasalahan yang dihadapi Jamkesmas (Jaminan Kesehatan Masyarakat) dimana Jamkesmas (Jaminan Kesehatan Masyarakat) adalah sebuah layanan kesehatan masyarakat secara gratis dari pemerintah yang dikelola oleh PT Askes (Persero). Namun sejak pertama diberlakukan, Jamkesmas terus menerus menghadapi permasalahan dan keluhan dari masyarakat. Dalam sebuah artikel di harian Kompas pada tahun 2010 disampaikan bahwa dalam pelaksanaannya, Jamkesmas ini mendapatkan kesan yang rumit dan membingungkan terutama bagi masyarakat miskin yang sebagian berpendidikan rendah, karena mereka terlebih dahulu harus melengkapi persyaratan dan mengikuti prosedur yang telah ditentukan (Chandra, 2010).

Pada pelaksanaannya, BPJS Kesehatan yang telah berjalan sejak tahun 2014 juga tidak terlepas dari permasalahan. Beberapa 
permasalahan yang harus dihadapi BPJS Kesehatan terutama di kota Bandung dalam kurun waktu terakhir ini antara lain: Demo buruh yang tergabung dalam Serikat Pekerja Seluruh Indonesia (SPSI) di depan kantor BPJS Kesehatan Pasteur yang meminta kelonggaran untuk menunda keikutsertaan sebagai peserta BPJS Kesehatan, karena selama ini perusahaan tempat mereka bekerja memaksa para pekerja untuk menjadi peserta BPJS Kesehatan dan para pekerja merasa keberatan (Roni Kurniawan, 2015); kasus lainnya yaitu Rumah Sakit di kota Bandung mengeluhkan adanya keterlambatan pembayaran klaim pasien BPJS Kesehatan yang mencapai Rp.73.26 Miliar, yang berasal dari 1.612.519 peserta BPJS Kesehatan Kota Bandung sejak awal tahun 2015 hingga akhir September 2015 (Cecep Wijaya, 2014). Selain itu masalah percaloan yang mencuat di BPJS Kesehatan Kota Bandung, dimana permasalahan ini terlihat setelah adanya keluhan warga tentang nomor antrean yang dijual belikan oleh calo (Ziyan, 2015).

Selain permasalahan di atas penulis juga melihat masih kurang maksimalnya sosialisasi tentang BPJS Kesehatan yang dilakukan oleh pemerintah dalam hal ini pengelola BPJS kesehatan, penulis melihat masyarakat justru lebih sering mendapatkan penjelasannya dari Dinas Kesehatan maupun Rumah Sakit. Kurangnya sosialisasi tersebut menimbulkan keluhan-keluhan dari masyarakat tentang BPJS Kesehatan terutama tentang layanan BPJS Kesehatan, mulai dari penolakan rumah sakit kepada peserta BPJS, diskriminasi pelayanan, kesulitan antrian yang dibatas waktunya, hingga bengkaknya tagihan pasien (Nugraha, 2015); dan terakhir adalah munculnya kisruh fatwa Majelis Ulama Indonesia (MUI) yang mengatakan bahwa BPJS Kesehatan haram yang mempengaruhi pandangan masyarakat sehingga masyarakat menjadi ragu untuk menjadi peserta BPJS Kesehatan. Padahal sebenarnya MUI sendiri tidak pernah mengeluarkan kalimat haram, pendapat yang dikeluarkan MUI tentang BPJS Kesehatan adalah berupa rekomendasi hasil kesepakatan bersama, sehingga ini belum berupa fatwa, namun hanya berupa rekomendasi kepada pemerintah yang artinya boleh dijalankan atau tidak (Junaedi, 2015).

Adapun keunikan yang penulis lihat berkaitan dengan BPJS Kesehatan ini adalah proses transformasi yang sudah berlangsung beberapa kali dan cukup menempuh perjalanan panjang selama 47 tahun. Dimulai pada tahun 1968 bernama Badan Penyelenggaran Dana Pemeliharaan Kesehatan (BPDPK), kemudian pada tahun 1984 bertransformasi dengan memperluas cakupan layanan. BPDPK ini kemudian bertransformasi kembali pada tahun 1992 yang sebelumnya berbentuk perum, berdasarkan PP Nomor 6 tahun 1992 status perum berubah penjadi PT (Persero) dengan nama PT Askes (Persero). Lantaran dinilai memiliki pengalaman yang cukup untuk mengelola jaminan kesehatan, akhirnya dengan disahkan dan diundangkannya UU Nomor 24 tahun 2011 tentang BPJS, akhirnya PT Askes (Persero) ditransformasikan menjadi BPJS Kesehatan. Masih adanya masalah demi masalah yang berkaitan dengan asuransi kesehatan milik pemerintah setelah berkali-kali melakukan tranformasi ini menarik perhatian penulis untuk membahas lebih lanjut dalam bentuk penelitian.

Permasalahan yang saat ini dihadapi oleh BPJS Kesehatan bisa bersumber dari berbagai macam faktor, seperti bersumber pada kurang maksimalnya sosialisasi yang dilakukan oleh pemerintah atau pengelola BPJS Kesehatan kepada masyarakat tentang BPJS Kesehatan, sehingga masyarakat sampai saat ini masih belum memahami tentang apa itu BPJS Kesehatan secara keseluruhan atau secara lebih mendalam atau bisa juga bersumber dari masyarakatnya itu sendiri misalnya kurang memiliki kesadaran untuk mencari tahu tentang BPJS Kesehatan atau memiliki sikap kurang sadar akan arti pentingnya asuransi kesehatan, atau ada faktor-faktor lainnya yang menjadi sumber permasalahan BPJS Kesehatan.

Berkembangnya persoalan yang dihadapi BPJS, tentunya melibatkan berbagai faktor yang perlu dikaji lebih mendalam dari berbagai sumber di lapangan. Dan secara konseptual atau teoritis, melalui teori Interaksi simbolik berusaha memahami perilaku manusia dari sudut pandang subjek, dimana perilaku manusia harus dilihat sebagai proses yang memungkinkan manusia membentuk dan mengatur perilaku mereka. Definisi yang mereka berikan kepada orang lain, situasi, objek, dan bahkan diri mereka sendirilah yang menentukan perilaku mereka. Teori interaksionisme simbolik yang mempelajari sifat interaksi merupakan kegiatan sosial dinamis manusia serta pemikiran umum tentang komunikasi dan masyarakat. 
Paham ini menolak gagasan bahwa individu adalah organisme pasif yang perilakunya ditentukan oleh kekuatan-kekuatan struktur yang ada di luar dirinya, oleh karena itu individu terus berubah maka masyarakat pun berubah melalui interaksi. Jadi, interaksilah yang dianggap variabel penting yang menentukan perilaku manusia, bukan struktur masyarakat (Mulyana, 2004: 61). Menurut Mulyana (2004: 64), perilaku mempunyai potensi komunikasi dan merupakan salah satu prinsipprinsip komunikasi. Apabila ditanya apa fungsi komunikasi maka salah satu jawabnya adalah sebagai suatu pernyataan eksistensi diri. Perilaku merupakan suatu komunikasi dimana dengan komunikasi dapat dicapai suatu pengakuan keberadaan atau eksistensi.

Komunikasi bukanlah sebuah ilmu yang eksklusif, komunikasi sering kali menjadi perlintasan atau perpaduan berbagai cabang ilmu lainnya. Sebagai cabang dari ilmu sosial, komunikasi juga menganggap bahwa manusia merupakan objek kajiannya. Komunikasi sebagai ilmu sosial berusaha untuk mengamati dan menafsirkan pola-pola perilaku manusia. (Mulyana, 2004: 18). Pemahaman akan manusia ini akan lebih mendekati akurat jika dilakukan pendekatan yang manusiawi, karena manusia dalam dirinya memiliki esensi kebudayaan, saling berhubungan, masyarakat, dan buah pikiran. (Fisher, 1990: 231).

Di dalam teori interaksi simbolik ini, yang menjadi fokus utama adanya hubungan interaksi yang intensif yang dapat menjadi alat ukur seberapa besar makna interaksi komunikasi tersebut. Di dalam melakukan interaksi tesebut kepada sesamanya maupun kepada seseorang yang normal. Lalu teori ini membangun kesadaran setiap manusia dalam berhubungan tidak hanya sebatas komunikasi dalam tata pergaulan namun juga lebih luas mencakup pada interaksi budaya, politik, ekonomi, sosial, dan bentuk kehidupan lainnya.

Dualisme diri manusia ke dalam dua wujud, yaitu saya (" $I$ ") dan aku ("Me") seperti diungkap Mead, merupakan sesuatu yang fundamental dalam proses penafsiran yang menjadi asumsi dasar yang melandasi interaksionisme simbolis. (Fisher, 1990: 231). Asumsi ini hendaknya dapat menjelaskan bagaimana manusia mengungkapkan dirinya sebagaimana orang lain memandang dirinya tersebut, dengan kata lain manusia sebagai makhluk sosial.
Sumber daya manusia yang mengelola dan menjalankan program BPJS, tentunya perlu melakukan upaya transformasi (perubahan) yang lebih baik dan signifikan. Menurut Kamus Besar Bahasa Indonesia (1988), transformasi adalah sebuah kata benda yang berarti perubahan rupa, bentuk (sifat, dsb). Transformasi dalam bentuk kata kerja menjadi mentransformasikan, yang berarti mengubah rupa, bentuk (sifat, fungsi, dsb) dan juga berarti mengalihkan. Pengertian sama dijelaskan oleh kamus yang lain yaitu Advanced EnglishIndonesian Dictionary (1988) menjelaskan yang dimaksud transformation adalah perubahan bentuk dan dalam bentuk kata kerja merubah bentuk. Selanjutnya, Oxford Learner's Pocket Dictionary (1995) menyebutkan transform sebagai kata kerja adalah "change completely the appearance or the character of". Berarti perubahan bentuk penampilan atau karakter secara total.

Menurut pendapat Thomas G. Cummings dan Christopher G. Worley (2008: 2-3) transformasi organisasi merupakan aplikasi keseluruhan sistem yang mencakup ilmu pengetahuan perilaku terhadap perubahan terencana, pengembangan, dan penguatan struktur strategi serta proses menuju efektifitas organisasi. Dapat dikatakan bahwa transformasi adalah perubahan bentuk, penampilan, atau karakter secara total. Transformasi atau perubahan pada organisasi ini merupakan salah satu kunci dalam mencapai pengembangan organisasi. Organisasi terus berubah karena ia adalah sistem terbuka yang selalu berinteraksi dengan lingkungannya. Perubahan yang direncanakan membutuhkan perhatian yang eksplisit terhadap masalah-masalah dan kesempatan-kesempatan, perubahan ini juga terbantu oleh beberapa pengalaman yang di dapatkan oleh suatu organisasi. Transformasi adalah seluruh proses perubahan yang diperlukan untuk memposisikan diri agar lebih baik dalam menyikapi dan menjawab tantangan-tantangan bisnis baru, lingkungan usaha yang berubah secara cepat maupun keinginan-keinginan baru yang muncul dari dalam.

Banyak pakar mengemukakan bahwa satusatunya yang tetap di dunia ini adalah perubahan itu sendiri. Oleh karena itu, perubahan dapat terjadi setiap saat, kapan saja situasimemerlukan. Perubahan terjadi, disamping karena timbulnya dorongan eksternal, tetapi juga dapat timbul 
dari adanya kebutuhan internal organisasi untuk melakukan perubahan (Wibowo, 2011: 1).

\section{METODE PENELITIAN}

Metode yang digunakan dalam penelitian ini adalah metode kualitatif. Dengan pendekatan studi kasus. Studi kasus adalah uraian dan penjelasan komprehensif mengenai berbagai aspek seorang individu, suatu kelompok, suatu organisasi (komunitas), suatu program, atau suatu situasi sosial. Penelitian studi kasus berupaya menelaah sebanyak mungkin data mengenai subjek yang diteliti (Yin, 2011: 21). Yin (2011: 31) menyebutkan bahwa studi kasus adalah salah satu metode penelitian ilmuilmu sosial serta kehidupan nyata, bilamana batas-batas antara fenomena dan konteks tak tampak dengan tegas dan dimana mulyisumber bukti dimanfaatkan. Secara umum studi kasus merupakan pendekatan penelitian yang leih cocok jika pertanyaan penelitian berkenaan dengan how (bagaimana) dan why (mengapa). Terdapat istilah yang berkaitan dengan studi kasus yaitu case history atau disebut riwayat kasus, sejarah kasus. Case history merupakan data yang terimpun yang merekonstruksikan masa lalu seorang individu, dengan tujuan agar orang dapat memahami kesulitan-kesulitannya yang sekarang serta menolongnya dalam usaha penyesuaian diri (adjustment) (Kartono dan Gulo, 2000).

Teknik sampling yang digunakan dalam penelitian ini adalah purposive sampling. Seperti yang sudah dikemunkakan Purposive Sampling adalah teknik pengambilan sumber data dengan pertimbangan terentu. Pertimbangan tertentu ini, misalnya orang tersebut yang dianggap paling tahu tentang apa yang kita harapkan, atau mungkin dia sebagai penguasa sehingga akan memudahkan peneliti menjelajahi obyek/situasi sosial yang akan diteliti (Sugiyono, 2011: 54). Pada penelitian ini, peneliti menggunakan teknik purposive sampling dengan menentukan Key informan yang akan menjadi narasumber yaitu orang-orang yang berkaitan langsung dengan BPJS Kesehatan dan merasakan manfaat langsung dari BPJS Kesehatan tersebut.

Teknik pengumpulan data adalah teknik yang digunakan dalam proses pengadaan data primer untuk kepentingan penelitian. Pengumpulan data adalah prosedur yang sistematis dan standar untuk memperoleh data yang diperlukan (Moleong, 2007: 134). Teknik pengumpulan data yang diperlukan dalam penelitian ini adalah wawancara mendalam (semi terstruktur), observasi dan studi kepustakaan. Teknik analisis data yang digunakan dalam penelitian ini berdasarkan pada teknik analisa data yang terdiri dari reduksi data, kategorisasi data, sintesisasi dan diakhiri dengan menyusun hipotesis.

Setiap penelitian memerlukan uji keabsahan data atau uji validitas, dan pemeriksaan terhadap keabsahan data mutlak dilakukan, sehingga penelitian tersebut benarbenar dapat dipertanggungjawabkan dari segala segi (Moleong, 2006: 320). Pengujian data ini diperlukan untuk membuktikan apakah data yang diperoleh sudah benar atau belum. Pengujian keabsahan data dalam penelitian ini dilakukan dengan perpanjangan pengamatan, dan teknik triangulasi

\section{HASIL DAN PEMBAHASAN}

BPJS Kesehatan merupakan hasil transformasi dari PT Askes (Persero) sejak tahun 2014. Secara aturan ataupun hukum sudah ada yang mendasari transformasi ini, namun untuk mengetahui lebih mendalam mengenai transformasi PT Askes (Persero) sejak tahun 2014 menjadi BPJS Kesehatan, peneliti melakukan wawancara dengan beberapa Kepala Staf dengan asumsi informan ini memiliki pemahaman yang lebih mendalam karena lama kerjanya sudah lebih dari 20 tahun yang terlibat sejak masih menjadi PT Askes (Persero) hingga menjadi BPJS Kesehatan saat ini. Adapun yang menjadi alasan dilakukannya transformasi ini menurut Wahyu Hermansyah adalah sebagai berikut:

"Askes kan hanya golongan PNS, sedangkan masalah ketenagakerjaan dikelola sama yang namanya Jamsostek. Kemudian berdasarkan UU kan negara kita harus punya program Jaminan Kesehatan Nasional, dan harus bisa diterima oleh semua lapisan masyarakat. Nah setelah itu Askes kemudian ditunjuk untuk mengelola JKN tersebut, namun berdasarkan undangundang, tidak boleh berbentuk PT sehingga diputuskan untuk menjadi badan milik negara sehingga namanya berubah menjadi BPJS Kesehatan. Begitu juga dengan Jamsostek tidak boleh PT lagi maka nya 


\section{diubah jadi BPJS"}

Hal serupa mengenai alasan dilakukannya transformasi, juga disampaikan oleh Dini Zubaedah berikut ini:

"Pada dasarnya transformasi ini dilakukan berdasarkan instruksi presiden dalam rangka menggalakkan program Jaminan Kesehatan Nasional. Jadi salah satu caranya adalah dengan menjadikan perusahaan BUMN Persero menjadi sebuah Badan Penyelenggara yang tugas utamanya menjamin kesehatan seluruh penduduk Indonesia tanpa kecuali."

Berdasarkan kedua hasil wawancara tersebut bisa dilihat bahwa transformasi yang terjadi adalah berdasarkan instruksi presiden yang kemudian dituangkan dalam Undangundang. Transformasi tersebut juga dapat terlihat dari tujuan utama BPJS Kesehatan yang tertuang dalam visinya yaitu "Paling lambat 1 Januari 2019, seluruh penduduk Indonesia memiliki jaminan kesehatan nasional untuk memperoleh manfaat pemeliharaan kesehatan dan perlindungan dalam memenuhi kebutuhan dasar kesehatannya yang diselenggarakan oleh BPJS Kesehatan yang handal, unggul dan terpercaya", sedangkan visi dari PT Askes (Persero) sendiri adalah "Menjadi spesialis dan pusat unggulan Asuransi Kesehatan di Indonesia" (Humas BPJS, 2010).

Menurut pendapat Thomas G. Cummings dan Christopher G. Worley (2008: 2-3) transformasi organisasi merupakan aplikasi keseluruhan sistem yang mencakup ilmu pengetahuan perilaku terhadap perubahan terencana, pengembangan, dan penguatan struktur strategi serta proses menuju efektifitas organisasi. Transformasi dari PT Askes (Persero) menjadi BPJS Kesehatan tentunya harus dipahami oleh semua divisi termasuk divisi pemasaran, terutama oleh pegawai yang sudah bekerja sejak BPJS Kesehatan masih bernama PT Askes (Persero). Untuk dapat lebih mengetahui bagaimana pemahaman pegawai divisi pemasaran BPJS Kesehatan kota Bandung ini, penulis mencoba mengetahui melalui sejauh mana pegawai BPJS Kesehatan memahami perbedaan antara PT Askes (Persero) dengan BPJS Kesehatan. Hal tersebut dijelaskan pada beberapa pernyataan Yulita Anggaini berikut:

"Perubahan yang paling terlihat mungkin dari segi sistem pembayaran ya, jika dulu langsung dipotong dari gaji bulanan, sekarang kan istilahnya kesadaran masingmasing peserta. Udah gitu juga dari visi misi juga ada bedanya, dimana kalo BPJS sekarang ini lebih kepada tujuan kemanusiaan bukan keuntungan."

Perubahan BPJS, tampaknya mulai dilakukan dalam sistem pembayaran yang berdasarkan pada kesadaran individu dan perubahan lainnya tentang logo, visi, misi dan lain sebagainya. Hal ini dikuatkan oleh Wahyu Hermansyah dan Dini Zubaedah berikut:

"Perubahannya mulai dari logo, visi, misi, struktur, sistem kerja, sistem rekrutmen dan lain-lain. Jadi sebenarnya dengan transformasi ini memang semua aspek ada perubahannya, mungkin hanya dari segi sumber daya manusianya saja yang tidak terlalu banyak berubah, hanya penambahan saja."

Demikian juga, pentingnya perubahan visi, misi BPJS akan memberi dampak yang lebih luas bagi pelaksanaan program berikutnya, seperti yang terungkap dalam wawancara dengan Dini Zubaedah berikut:

"Visi dan misi adalah perubahan yang paling krusial ya, soalnya dari visi dan misi ini kemudian akan terbentuk lagi sistem - sistem lain dibawahnya yang diimplementasikan berdasarkan misi yang diemban oleh BPJS Kesehatan sehingga tujuan dan targetnya menjadi lebih jelas."

Pernyataan Dini Zubaedah di atas, dikuatkan oleh Asepudien bahwa "Banyak hal sih yang berubah ya, mulai dari cara kerja, sistem kerja, sistem pembayaran, sistem pengobatan". Namun, ditambahkan juga bahwa persoalan keuntungan BPJS, tampaknya belum menjadi target utama, namun lebih menekankan kemanusiaan dan gotong royong, seperti yang terungkap dalam wawancara dengan Sulistiawati berikut: "Yang jelas efeknya disini bukan dari segi keuntungan, tapi dari segi gotong royong karena prinsipnya adalah subsidi silang. Jadi yang sehat itu membantu yang sakit, dan sebaliknya. Tidak ada prinsip rugi karena pada dasarnya saling membantu satu sama lain". Hal ini sejalan dengan pemikiran Budyatna (2012), bahwa Indonesia dikatakan sebagai negara yang 
memiliki kebudayaan kolektivisme dimana budaya kolektivisme itu sendiri dicirikan dengan tendensi susunan kepentingan bersama atas kepentingan individu (Prastantri, Novianti, \& Romli, 2017).

Berdasarkan hasil wawancara tersebut, dapat terlihat bahwa ada beberapa hal yang dipersepsikan paling terlihat perubahannya setelah adanya transformasi, yaitu: (1) Visi dan misi. Pada visi dan misi dikatakan bahwa PT Askes (Persero) lebih kepada memajukan perusahaan agar menjadi unggul dan mampu bersaing dengan perusahaan asuransi kesehatan lainnya, sedangkan visi dan misi BPJS Kesehatan lebih kepada menjalankan amanat Undang-undang Dasar untuk meningkatkan taraf kesehatan masyarakat Indonesia secara umum. (2) Orientasi dan tujuan organisasi. BPJS Kesehatan memiliki orientasi kepada kepentingan masyarakat, sedangkan PT Askes (Persero) lebih kepada orientasi keuntungan perusahaan. Perbedaan orientasi dan tujuan ini tentunya juga akan menjadi tolok ukur bagi organisasi/perusahaan tersebut dalam memberikan pelayanan kepada para peserta. Oleh karena itu dibutuhkan pelatihan tentang meningkatkan kualitas pelayanan kesehatan (Kosasih, Setianti, \& Wahyudin, 2017)

Semua pegawai BPJS Kesehatan pada dasarnya wajib untuk memahami secara mendalam tentang segala sesuatu yang berhubungan dengan transformasi PT Askes (Persero) menjadi BPJS Kesehatan karena itu merupakan tugas dan tanggung jawab mereka. Dengan memiliki pemahaman yang mendalam pegawai BPJS Kesehatan akan dapat memiliki kesempatan atau kemampuan yang lebih baik untuk memberikan informasi kepada masyarakat tentang BPJS Kesehatan dan pada akhirnya dapat membentuk citra positif BPJS Kesehatan dimata masyarakat. Citra dan eputasi merupakan bagian dari ilmu Public Relations. (Hidayat et al., 2017), oleh karena itu perlu dilakukan penerapan strategi yang berbasis pada hubungan yang terjalin baik dengan publik sasaran.

Selain pemahaman pegawai tentang BPJS Kesehatan faktor penting lainnya adalah tanggapan dan persepsi dari masyarakat terhadap transformasi transformasi PT. Askes Indonesia Persero menjadi BPJS Kesehatan. Untuk mengetahui seperti apa persepsi masyarakat mengenai BPJS Kesehatan, penulis melakukan wawancara dengan beberapa peserta BPJS Kesehatan yang sebelumnya juga merupakan peserta PT Askes Persero Indonesia, adapun tanggapan dan persepsi dari masyarakat, yaitu Ardhani adalah sebagai berikut: "Setau saya sih pembiayaannya lebih luas BPJS Kesehatan ya dibanding waktu saya pake Askes dulu. Dan sistemnya juga mudah aja Cuma mungkin orang lain ngelihat pelayanan pasien yang pake BPJS Kesehatan itu lebih lambat karena memang mengantri."

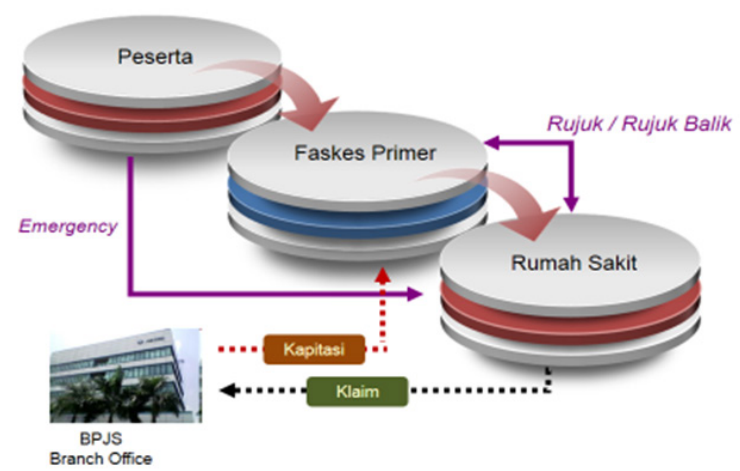

Gambar 1 Prosedur Pelayanan Kesehatan BPJS Kesehatan ( BPJS, 2016)

Dari hasil wawancara tersebut dapat terlihat adanya manfaat atau perubahan yang dirasakan masyarakat setelah PT Askes (Persero) melakukan transformasi menjadi BPJS Kesehatan, namun selain manfaat ada juga pendapat yang mengatakan kalau prosedur menggunakan BPJS seperti yang tampak pada Gambar 1 dirasakan masih terlalu rumit dimana seharusnya pemerintah bisa mengantisipasi masalah tersebut karena masalah tersebut sudah ada sejak PT Askes (Persero) masih belum melakukan transformasi menjadi BPJS Kesehatan seperti diungkapkan Wawan selaku Komite Aksi Jaminan Sosial (KAJS) kepada penulis:

"..bahwa sejak masih bernama PT Askes Indonesia, hingga sekarang menjadi BPJS Kesehatan, layanan asuransi kesehatan milik pemerintah ini tidak berhenti mendapatkan keluhan, terutama soal lambatnya pelayanan, hingga kesulitan dalam mendapatkan kartu kepesertaan, sehingga hal tersebut harus terus menerus diperhatikan oleh pemerintah agar paling tidak mengurangi tingkat keluhan yang masuk dan membantu masyarakat sehingga tidak lagi enggan untuk menjadi peserta BPJS Kesehatan..." 
UU SJSN dan UU BPJS memberi arti kata 'transformasi' sebagai perubahan bentuk BUMN Persero yang menyelenggarakan program jaminan sosial, menjadi BPJS. Perubahan bentuk bermakna perubahan karakteristik badan penyelenggara jaminan sosial sebagai penyesuaian atas perubahan filosofi penyelenggaraan program jaminan sosial. Perubahan karakteristik berarti perubahan bentuk badan hukum yang mencakup pendirian, ruang lingkup kerja dan kewenangan badan yang selanjutnya diikuti dengan perubahan struktur organisasi, prosedur kerja dan budaya organisasi.

Dengan melihat pengertian dari transformasi diatas seharusnya pemerintah segera melakukan perbaikan-perbaikan baik dari struktur organisasi, prosedur kerja dan budaya organisasi agar pelayanan yang diberikan oleh BPJS Kesehatan kepada masyarakat menjadi lebih baik dan pada akhirnya dapat menarik minat masyarakat untuk menjadi peserta BPJS Kesehatan serta mampu menghadapi persaingan dengan perusahaan asuransi milik swasta dimana pada akhirnya apa yang menjadi visi dan misi BPJS Kesehatan bisa tercapai dimana misinya yaitu paling lambat 1 Januari 2019, seluruh penduduk Indonesia memiliki jaminan kesehatan nasional untuk memperoleh manfaat pemeliharaan kesehatan dan perlindungan dalam memenuhi kebutuhan dasar kesehatannya yang diselenggarakan oleh BPJS Kesehatan yang handal, unggul dan terpercaya, sedangkan visi dari PT Askes (Persero) sendiri adalah Menjadi spesialis dan pusat unggulan Asuransi Kesehatan di Indonesia.

Beberapa informan yang merupakan pegawai swasta, yaitu Ardhani menyampaikan alasan mereka belum menggunakan fasilitas BPJS Kesehatan sebagai berikut: "Mungkin karena kalo BPJS itu kan ada alur pelayanannya ya, jadinya ngga langsung gitu harus dari klinik dulu dan seterusnya, sedangkan kalo misalnya kita lagi ke rumah sakit kan karena kondisi yang darurat gitu ya, jadi kurang efektif aja menurut saya sih". Begitu juga dengan yang dikemukakan Darwis, yaitu: "Proses nya lama kali ya, apalagi kalo misalnya pas lagi jam kerja gitu kan kita pengen dapat pelayanan yang cepet"

Kedua informan tersebut menyampaikan tentang permasalahan alur pelayanan kesehatan dari BPJS Kesehatan, dimana alur pelayanan kesehatan dari BPJS Kesehatan terlalu panjang prosesnya. Adapun alur pelayanan yang dimaksud, dipaparkan sebagai berikut (BPJS Kesehatan, 2014): (1) Peserta BPJS Kesehatan membawa kartu BPJS Kesehatan atau kartu anggota ASKES yang lama, mendatangi fasilitas kesehatan tingkat pertama tempat peserta terdaftar (Puskesmas, dokter keluarga, klinik TNI/POLRI, dan fasilitas kesehatan setingkat itu). Pada tahap ini peserta akan mendapatkan pelayanan kesehatan sesuai kompetensi dan kapasitas fasilitas kesehatan di tingkat pertama tersebut (seperti konsultasi kesehatan, laboratorium klinik dasar dan obatobatan).

Selanjutnya, (2) Apabila setelah pemeriksaan awal pasien belum sembuh, maka pasien dirujuk ke fasilitas kesehatan tingkat lanjutan (Rumah Sakit Pemerintah, Rumah Sakit Swasta, Rumah Sakit TNI-POLRI yang bekerjasama dengan BPJS Kesehatan). Sedangkan untuk kondisi gawat darurat, peserta BPJS Kesehatan bisa mendapatkan pelayanan fasilitas kesehatan tingkat lanjutan, tanpa mendapatkan rujukan dari fasilitas kesehatan tingkat pertama. (3) Di fasilitas kesehatan tingkat lanjutan, peserta menunjukkan kartu BPJS Kesehatan atau kartu lama dan surat rujukan Fasilitas Kesehatan Tingkat Pertama kepada petugas BPJS Kesehatan Center.

Berikutnya, (3) petugas akan menerbitkan surat Eligibilitas Peserta (SEP) sebagai dokumen yang menyatakan bahwa peserta dirawat dengan biaya BPJS Kesehatan. (4) Setelah mendapatkan SEP, pasien akan mendapatkan pelayanan kesehatan di Fasilitas Kesehatan Tingkat Lanjutan, baik untuk pelayanan rawat jalan ataupun rawat inap. Apabila penyakit pasien dapat ditangani tanpa harus mendapatkan perawatan inap, pasien boleh pulang atau dirujuk kembali ke fasilitas kesehatan tingkat pertama. Sedangkan untuk pasien dengan penyakit kronis, dapat masuk ke dalam program pengelolaan penyakit kronis (Prolanis) di fasilitas kesehatan tingkat pertama tersebut.

Adapun pelayanan kesehatan yang dijamin antara lain adalah: (1) Administrasi pelayanan; (2) Pelayanan promotif dan preventif; (3) Pemeriksaan, pengobatan, dan konsultasi medis; (4) Tindakan medis non spesialistik, baik operatif maupun non operatif; (5) Pelayanan obat dan bahan medis habis pakai; 


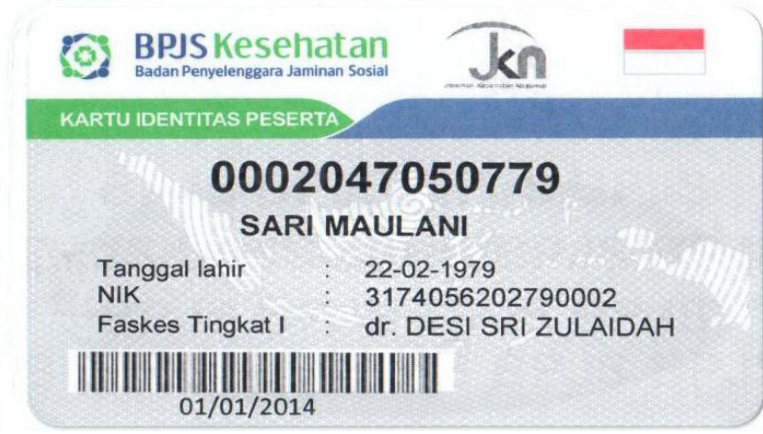

PUSAT LAYANAN INFORMASI BPJS KESEHATAN 500400

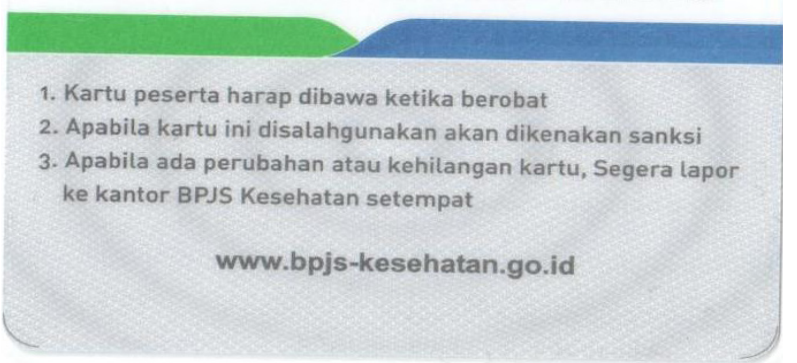

Gambar 2 Contoh Kartu Peserta BPJS Kesehatan

(6) Transfusi darah sesuai dengan kebutuhan medis; (7) Pemeriksaan penunjang diagnostik laboratorium tingkat pratama; dan (8) Rawat inap tingkat pertama sesuai dengan indikasi. (BPJS Kesehatan, 2014). Para pegawai yang memiliki gaji bulanan, biasanya memiliki alternatif atau pilihan asuransi kesehatan lainnya yang berasal dari pihak swasta. Meskipun dengan biaya iuran bulanan yang lebih mahal dibandingkan BPJS Kesehatan, namun asuransi swasta ini dianggap lebih mudah untuk digunakan karena alur pelayanannya yang bisa langsung ditujukan ke rumah sakit yang diinginkan.

Berdasarkan hasil pengamatan dan wawancara penulis dengan beberapa masyarakat umum, BPJS Kesehatan ini memang pada dasarnya memiliki manfaat yang besar bagi masyarakat, karena BPJS Kesehatan ini memberikan kemudahan bagi setiap orang yang ingin berobat, sehingga tidak ada lagi sebuah istilah dimana masyarakat kecil tidak bisa berobat karena keterbatasan biaya. Namun masih ada beberapa pembenahan yang harus dilakukan oleh BPJS Kesehatan dalam rangka mencapai pelayanan yang maksimal kepada masyarakat, dan ini bukan saja tugas BPJS Kesehatan, tapi juga merupakan tugas dari pemerintah Indonesia secara umum.

Pemerintah perlu meningkatkan jumlah fasilitas kesehatan agar sebanding dengan banyaknya peserta yang berobat. Lalu Upaya Kesehatan Masyarakat (UKM) juga harus bisa berjalan dengan baik. Menurut penulis akan terlalu berat untuk BPJS Kesehatan jika UKM yang dimaksud tidak berjalan dengan baik, sehingga nantinya akan jelas apa yang menjadi posisi fasilitas kesehatan primer, sekunder dan tersier.

\section{SIMPULAN}

Berdasarkan paparan dan analisa yang disajikan, penelitian ini menghasilkan beberapa simpulan, yaitu sebagai berikut: Alasan yang melatarbelakangi transformasi PT Askes (Persero)menjadiBPJSKesehatan adalahadanya keinginan pemerintah agar seluruh penduduk Indonesia memiliki jaminan kesehatan nasional untuk memperoleh manfaat pemeliharaan kesehatan dan perlindungan dalam memenuhi kebutuhan dasar kesehatannya melalui BPJS Kesehatan. Serta adanya keinginan pemerintah untuk menciptakan lembaga penyelenggara sosial yang handal, unggul dan terpercaya serta menjadi spesialis dan pusat unggulan asuransi kesehatan di Indonesia.

Pemahaman staf divisi pemasaran mengenai transformasi dari PT Askes (Persero) menjadi BPJS Kesehatan penulis rasakan cukup baik, hal tersebut dapat terlihat dari pemahaman pegawai BPJS Kesehatan tentang tujuan utama dari transformasi PT Askes (Persero) menjadi BPJS Kesehatan adalah sebagai bentuk upaya pemerintah Indonesia dalam memajukan tingkat kesehatan dan taraf hidup masyarakat Indonesia secara keseluruhan serta memahami adanya perubahan pada visi, misi, orientasi organisasi serta pada praktek pengembangan SDM.

Tanggapan dan persepsi peserta mengenai BPJS Kesehatan pasca transformasi penulis lihat masih beragam mulai dari tanggapan yang berifat positif ataupun negatif. Hal tersebut dapat terlihat dari adanya tanggapan peserta tentang BPJS Kesehatan dimana BPJS Kesehatan dianggap sebagai sebuah solusi atau cara yang tepat bagi pemerintah jika ingin meningkatkan taraf kesehatan masyarakat Indonesia namun ada juga tanggapan bahwa BPJS Kesehatan sejauh ini masih kalah bersaing atau kurang efektif jika dibandingkan dengan perusahaanperusahaan asuransi swasta. Namun hampir sebagian peserta menaruh keinginan besar pada BPJS Kesehatan agar bisa berkembang dengan 
lebih baik.

Beberapa saran yang dapat diusulkan dari penelitian ini adalah sebagai berikut: BPJS Kesehatan sebaiknya lebih banyak melakukan sosialisasi tentang BPJS Kesehatan kepada masyarakat serta mensosialisasikan pula tentang arti pentingnya asuransi kesehatan agar masyarakat menjadi lebih mengerti dan lebih memahami akan arti pentingnya asuransi kesehatan.

BPJS Kesehatan sebaiknya sering melakukan evaluasi terhadap kebijakan yang dikeluarkannya agar bisa sesuai dengan keinginan dan harapan dari masyarakat Indonesia, misalnya seperti evaluasi pada alur pelayanan BPJS Kesehatan dimana masih banyak masyarakat yang menganggap alur pelayanan BPJS Kesehatan itu terlalu rumit.

BPJS Kesehatan sebaiknya sesegera mungkin mengembangkan fasilitas-fasilitas kesehatan secara merata di seluruh daerah di Indonesia, agar masyarakat yang membutuhkan pelayanan kesehatan darurat, dapat dengan sesegera mungkin dilayani.

\section{DAFTAR PUSTAKA}

Alwi, H. (2007). KBBI, edisi ketiga. Jakarta: Balai Pustaka

BPJS Kesehatan. (2014). Buku panduan praktis pelayanan kesehatan. Jakarta: BPJS Kesehatan

Chandra, A. (2010). Cakupan universal jamkesmas berat terlaksana untuk tahun 2014. Diakses dari http://health.kompas. com

Cummings, T, G. \& Worley, C, G. (2008). Organization development \& change, 9th Edition. USA: Cengage Learning

Fisher, A, B. (1990). Perspective on human communication. (teori-teori komunikasi): New York

Hidayat, D., Kuswarno, E., Zubair, F., \& Hafiar, H. (2017). Message platform atribut siger lampung di dalam kebhinekaan multikultur. Jurnal Kajian Komunikasi, 5(1), 91-101
Humas BPJS. (2010). Visi dan misi. Diakses dari http://bpjs kesehatan.go.id

Humas BPJS. (2013). Landasan hukum. Diakses dari http://bpjs-kesehatan.go.id

Junaedi, U. (2015). MUI: BPJS kesehatan bukan haram tetapi tidak sesuai syari'ah islam. Diakses dari http://www.kompasiana.com/ ucijunaedi/mui-bpjs-kesehatan-bukanharam-tetapi-tidak-sesuai-syari-ah-islam

Kartono, K. \& Gulo, D. (2000.) Kamus psikologi. Bandung: Pionir

Kosasih, E. J., Setianti, Y., \& Wahyudin, U. (2017). Pengaruh kredibilitas petugas terhadap sikap kepatuhan pasien tbc pada pemeriksaan dahak. Jurnal Kajian Komunikasi, 5/1, 1-10

Kurniawan, R. (2015). Ribuan buruh geruduk kantor bpjs kesehatan di bandung. Diakses dari http: //jabar.metrotvnews.com

Moleong, L, J. (2007). Metodologi penelitian kualitatif, Bandung: Remaja Rosdakarya

Mulyana, D. (2004). Metodologi penelitian kualitatif. Bandung: Remaja Rosdakarya

Nugraha, A. (2015). Kemana sosialisasi dari BPJS. Diakses dari http://www.prfmnews. com

Pratama. M, I. (2015). Pengaruh rebranding terhadap citra bank jambi pada nasabah, Jurnal Kajian Komunikasi. Diakses dari http://journal.unpad.ac.id/jkk/article/ view/7404/3406

Prastantri, A. S., Novianti, E., \& Romli, R. (2017). Identitas sekolah cinta budaya bangsa indonesia pada sekolah cakra buana. PRofesi Humas, 2/1

Sugiyono. (2012). Metode penelitian kuantitatif kualitatif dan $r \& d$. Bandung: Alfabeta

Wijaya, C. (2014). Klaim BPJS kesehatan kabupaten bandung capai rp 187 miliar. Diakses dari http://www.pikiran-rakyat. com

Yin, R, K. (2011). Studi kasus (desain dan metode). Jakarta: Raja Grafindo Persada

Ziyan. (2015). BPJS kab. bandung investigasi isu praktek percaloan. Diakses dari http:// galamedianews.com 